\title{
Spring bloom of Alexandrium tamarense in Chinhae Bay, Korea
}

\author{
Hae-Ok Lee ${ }^{1}$, Keun-Hyung Choi $^{2}$, Myung-Soo Han ${ }^{1, *}$ \\ ${ }^{1}$ Department of Life Science, College of Natural Sciences, Hanyang University, Seoul 133-791, Korea \\ ${ }^{2}$ Romberg Tiburon Center, San Francisco State University, Tiburon, California 94920, USA
}

\begin{abstract}
Chinhae Bay, one of the most eutrophic coastal embayments in Korea, is known for recurring red-tide blooms. To understand bloom development of the toxic dinoflagellate Alexandrium tamarense, weekly sampling was carried out from March to May of 1996 and 1997 in 2 regions, reflecting different flow regimes: one region (2 sites) was more susceptible to the influence of freshwater discharge than the other (2 sites). Nutrient concentrations remained high at nearly all depths throughout the study periods, suggesting that $A$. tamarense was not nutrient-limited for growth. A. tamarense cell density comprised $<5 \%$ of the total phytoplankton cell density at all times, in accordance with previous claims that this motile phytoplankton is unlikely to out-compete other spring bloom phytoplankton in high nutrient-level environments. The blooms occurred in a relatively wide temperature window ( 11 to $\left.18^{\circ} \mathrm{C} \mathrm{SST}\right)$, but in a narrow range of salinity (31 to 33 psu), and were associated with a stratified water column. Prolonged high temperature or reduced water column stability were ascribable for the demise of the blooms. In cases when blooms disappeared, even under favorable environmental conditions, life-cycle transition via sexual reproduction may have been responsible for their demise. Physical dilution processes, such as advection and dispersion, appeared to determine the magnitude of blooms, as supported by the occurrence of larger blooms and higher in situ growth rates in locations less subjected to the direct influence of river runoff or tidal currents.
\end{abstract}

KEY WORDS: Alexandrium tamarense $\cdot$ Bloom dynamics $\cdot$ Chinhae Bay

\section{INTRODUCTION}

The dinoflagellate Alexandrium tamarense can produce a neurotoxin which can be accumulated through the food web and cause paralytic shellfish poisoning (PSP). A. tamarense blooms have been reported to occur in embayments (Anderson et al. 1983, Su et al. 1993) and open coastal waters (Therriault et al. 1985, Franks \& Anderson 1992); these blooms, and the associated risk of PSP, are now becoming a recurrent problem in many coastal regions of the world.

Attempts have been made to relate environmental and ecological factors with Alexandrium tamarense bloom dynamics: temperature and salinity (Watras et al. 1982, Yamamoto et al. 1995), salinity, wind speed and tidal energy dissipation (White 1987), degree of water stratification (Cembella \& Therriault 1989), and cyst abundance and life-cycle transitions (Anderson et al. 1983, Wyatt \& Jenkinson 1997, Anderson 1998). It is difficult, however, to generalize environmental and ecological controls of $A$. tamarense bloom dynamics because its response varies with habitat and time.

Chinhae Bay is located in the southeastern part of Korea and connected through a narrow mouth to open seawater (Fig. 1). Water quality in the inner part of the bay has been aggravated since the 1970s due to increased inputs of domestic and industrial wastes (Lee et al. 1981, Yang 1989). During the last 2 decades, harmful algal blooms by Ceratium fusus and Gymnodinium nagasakiense have frequently occurred (Cho 1979, Lee et al. 1998). Occurrence of Alexandrium tamarense in Chinhae Bay was first reported in March 1989 (Han et al. 1992), although the presence of the PSP toxin in shellfish was reported earlier (Jeon et al. 1988). Spring cell-density of $A$. tamarense has since been on the rise, and subsequent studies on morphol- 
ogy, toxicity, cysts, and physiology of A. tamarense have been made (Lee 1990, Kim et al. 1993, Kim \& Lee 1996, Kim et al. 1996, Lee et al. 2000, Kim et al. 2002).

Little is known, however, of the factors affecting the initiation, development, and decline of Alexandrium tamarense in Chinhae Bay. We present spring population dynamics of A. tamarense in Chinhae Bay in 1996 and 1997, in an attempt to elucidate the relationship of A. tamarense dynamics to environmental variables (e.g. water temperature, salinity, water column stratification, and inorganic nutrients).

\section{MATERIALS AND METHODS}

Sampling of waters and analysis. The 4 sampling sites in Chinhae Bay, Korea, were selected to represent 2 flow regimes (see also below), with 2 of the sites being affected by a greater influence of river discharge (Stn M1 in 1996 and Stn M2 in 1997) than the other 2 sites (Stn C1 in 1996 and Stn C2 in 1997) (Fig. 1). Within the M sites, Stn M2 was more directly influenced by river runoff and the discharge from an adjacent sewage treatment facility, located west of Stn M2, than Stn M1. Within the C sites, Stn C1 was more directly affected by tidal currents than Stn C2. The results from the 4 sampling sites, therefore, were treated quasi-independently.

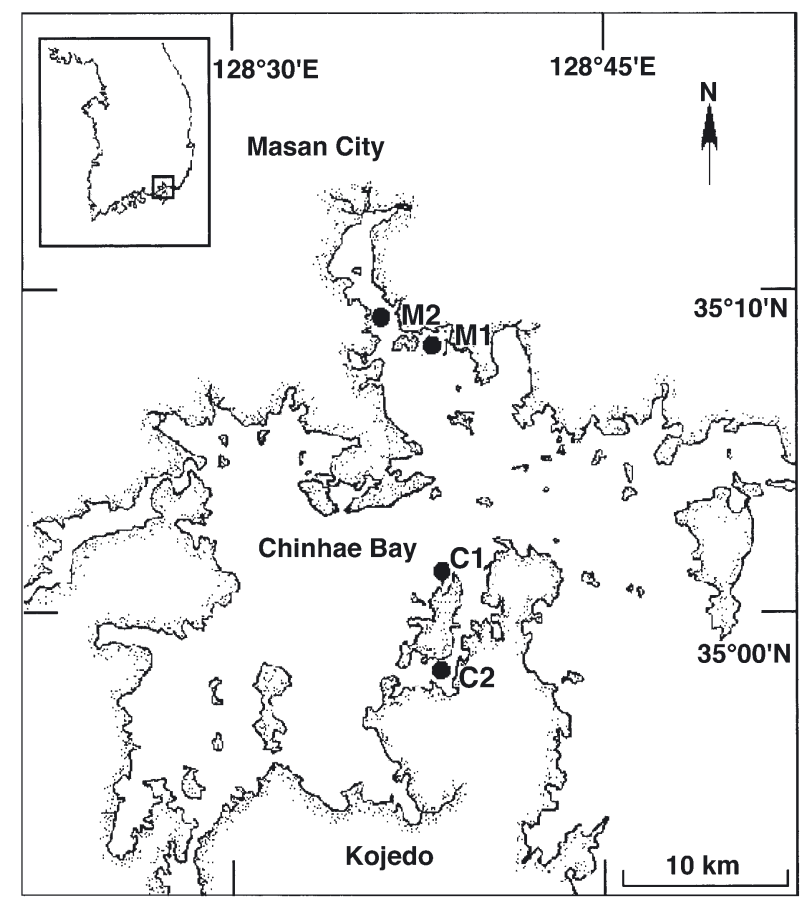

Fig. 1. Sampling stations in Chinhae Bay, Korea, in spring of 1996 (Stns M1 and C1) and 1997 (Stns M2 and C2)
Weekly sampling was conducted at Stns M1 (13 m depth) and C1 (15 m) from March 15 to May 31 in 1996, and at Stns M2 (14 m depth) and C2 (15 m) from March 7 to May 27 in 1997 (Fig. 1). Water samples were collected from various depths $(0,2,4,6,8$, and $12 \mathrm{~m})$ using a Van-Dorn sampler. Water temperature and salinity were measured on board with a portable T-S meter (ACT20-D, Alec Electronics). Data of averaged daily wind speed and precipitation were obtained from the Atmospheric Environment Service of Korea.

Water samples for dissolved inorganic nutrients were filtered through Whatman GF/F glass-fiber filters. Nutrient concentrations were determined with a Skalar Auto Analyzer 3100 following Parsons et al. (1992).

Phytoplankton samples $(300 \mathrm{ml})$ were preserved with glutaraldehyde (final concentration of $0.3 \%$ ). Fixed samples were concentrated by settling and identification of Alexandrium tamarense by microscopic examination (Carl Zeiss, Axioplan 400 to $1000 \times$ magnification) after dissecting thecal plates in a $5 \%$ sodium hypochlorite solution.

Data analysis. Data analyses for the relationship between measured variables and Alexandrium tamarense abundance were performed using an exploratory approach, with emphasis on graphic techniques (Cleveland 1993). Correlation analysis was carried out to assess the effects of temperature, salinity, stratification index (maximum vertical difference in water density at each sampling time), and inorganic nutrients on the variation of $A$. tamarense abundance. Prior to statistical analyses, 1 was added to the value of all data, averaged over depth, and naturallog-transformed to approximately equalize variance. Normality of the data was examined using the Kolmogorov-Smirnov test.

\section{RESULTS}

\section{Hydrographic condition}

Both numerical experiments and in situ measurements of currents in Chinhae Bay showed that the tidal current is strongly influenced by both bathymetry and geometry (Kim 1994, Kim et al. 1994). Major tidal currents shift from a south-easterly direction at the entrance of the Bay to a north-easterly direction around the northern section near Stn C1 (see Fig. 1), showing upward convexity. The current in the inner part of the Bay (Stn M2) is greatly influenced by wind and river runoff, as well as by tidal currents. The flow velocity during floods can exceed $0.9 \mathrm{~m} \mathrm{~s}^{-1}$ at Stn M2, where the predominant flow is in a north to south direction, whereas it only reaches $<0.3 \mathrm{~m} \mathrm{~s}^{-1}$ during 
floods at the other sites. In addition to the north-tosouth component, there also exists an east-to-west flow component at Stns M1 and C1. The flow rates at these sites, therefore, could even be lower because of possibly offsetting each other's flow component (Kim et al. 1994). River runoff during floods is primarily through 2 rivers near Masan City (Fig. 1).

There was intermittent precipitation throughout the study periods in both years, with greater fluctuation in 1997 (Fig. 2). The subsequent river runoff following rainfall was reflected in the salinity. The maximum rainfall at Stn M2 occurred on May 7, 1997, reaching $110 \mathrm{~mm} \mathrm{~d}^{-1}$, which was followed by a significant drop in salinity, but mostly at the surface. There was a relatively large drop in salinity at Stn M1 throughout the entire water column around May 1, which may have been attributed to the 2 precedent consecutive rainfalls. Although subdued, the effect of freshwater discharge was shown at Stns C1 and C2, but with a slight delay. Average wind speed during the study periods was $2.4 \mathrm{~m} \mathrm{~s}^{-1}$ in 1996 and $2.2 \mathrm{~m} \mathrm{~s}^{-1}$ in 1997, with greater fluctuation in 1997 (Fig. 2).

Water temperature steadily increased over time during the sampling periods, and its vertical difference

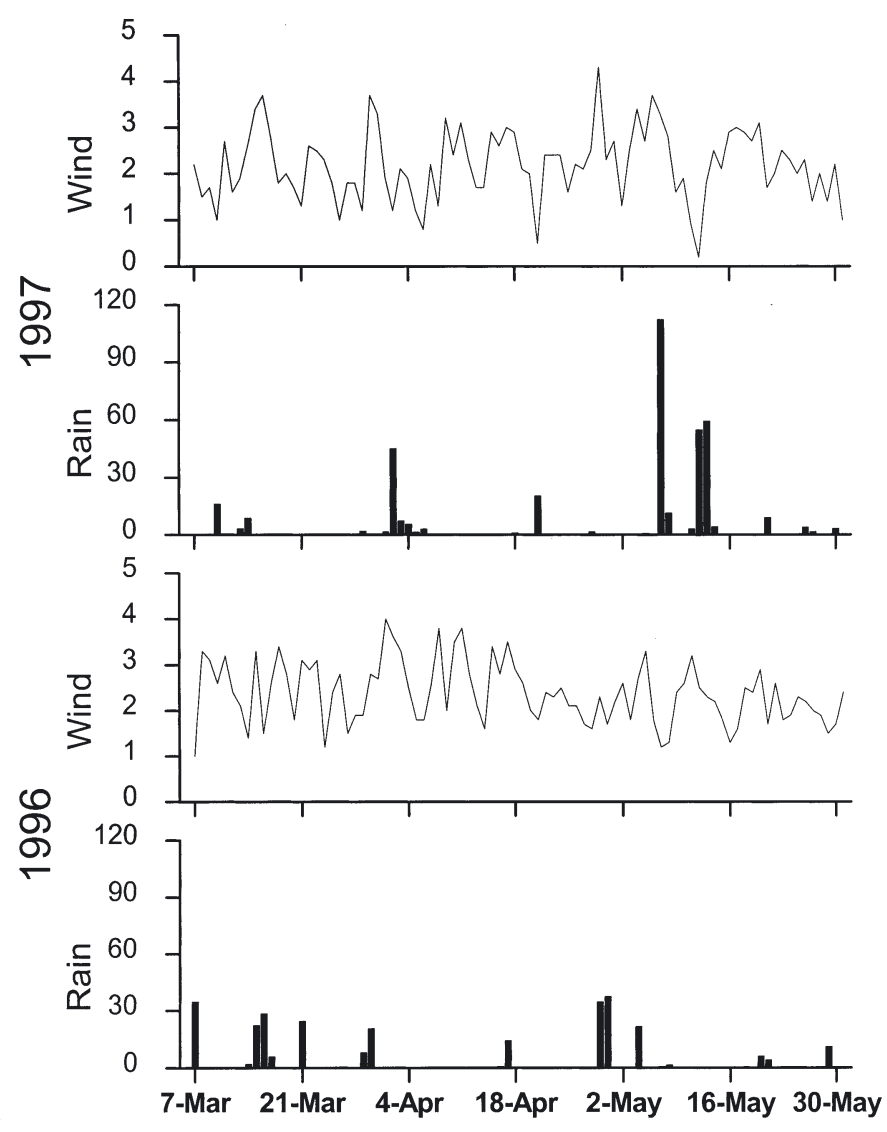

Fig. 2. Precipitation (rain; $\mathrm{mm}$ ) and averaged daily wind speed $\left(\mathrm{m} \mathrm{s}^{-1}\right)$ in Chinhae Bay increased towards late April and May by faster vernal warming at the surface (Fig. 3). As with the gradual increase of temperature and the decrease of salinity, the water column became stratified, although the degree and time of the stratification varied among sites. The water column during late April and May was stratified the least at Stn C1 and the most at Stn M2, possibly because of the greater influence of tidal currents and freshwater discharge (Table 1, Fig. 3B,C).

\section{Nutrients}

The nutrient concentration was, except for $\mathrm{SiO}_{2}$, highest at Stn M2 (Table 1), directly affected by river runoff and the discharge from an adjacent sewage treatment plant located west of Stn M2. Though far from the river runoff, Stn C2, where water exchange with adjacent areas may be restricted, displayed the second highest nutrient concentration. Stn M1 followed the next, and Stn C1, under the direct influence of tidal currents, showed the lowest concentration. In 1996, beginning May 9, there were sudden, sharp 2- to 3-fold increases in $\mathrm{PO}_{4}{ }^{3-}, \mathrm{NO}_{2}{ }^{-}$, and $\mathrm{SiO}_{2}$ at $\mathrm{Stn} \mathrm{C} 1$. The sharp increase also appeared at Stn M1, with a slight increase also in $\mathrm{NH}_{4}{ }^{+}$, but to a lesser degree in $\mathrm{SiO}_{2}$ (Fig. 3A,B). The elevated nutrient levels persisted throughout the rest of the study period. There was, however, no such persistent increase of nutrients at Stns C2 and M2 in 1997 (Fig. 3C,D). The increased nutrient concentration indicated that there may have been a switch in source water or additional input of the nutrients to the region.

\section{Alexandrium tamarense dynamics}

Alexandrium tamarense biomass constituted only a small fraction $(<5 \%$ at any time of the sampling periods, Table 1) of the total phytoplankton cell density, and the contribution of $A$. tamarense to total phytoplankton abundance was significantly higher at Stn C2 than at the other sites. The most dominant phytoplankton at Stn M1 was Pseudonitzchia seriata f. seriata, which occurred from March 15 to April 19, and thereafter Eutreptiella gymnastica became most dominant. $P$. seriata f. seriata dominated at Stn C1 throughout the study period. The dominant phytoplankton at Stns C2 and M2 were not determined.

Although the method to define an algal bloom varies (Smayda 1997), in order to facilitate the description of bloom initiations, a bloom of Alexandrium tamarense is defined in this study as $>10000$ cells $~^{-1}$. The onset of A. tamarense density development was not identical among sites (Fig. 3). There were 2 blooms at Stns M1 

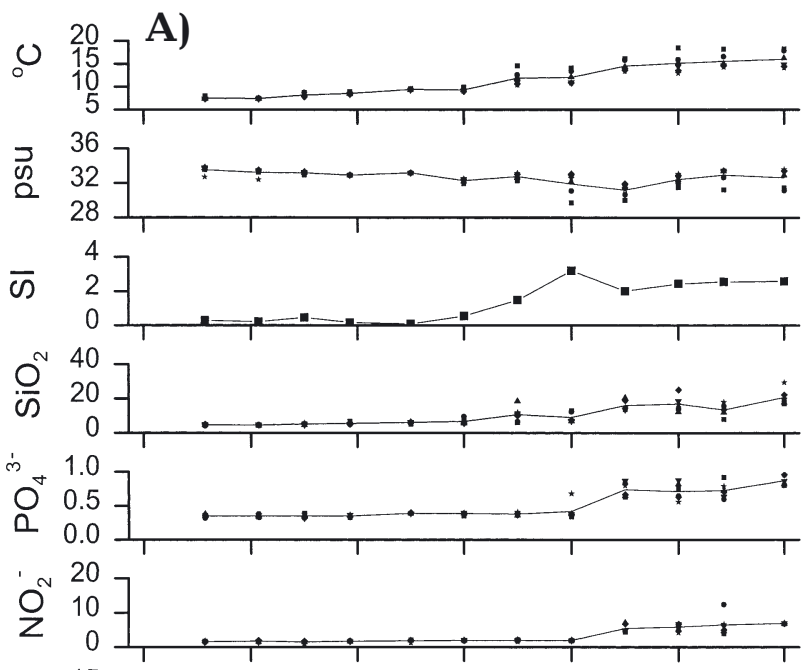

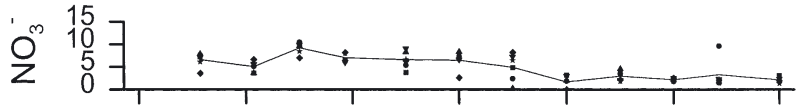

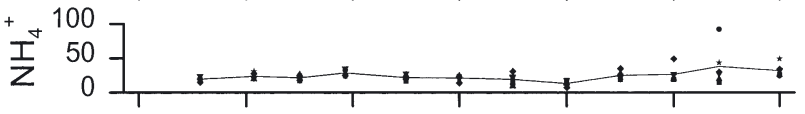

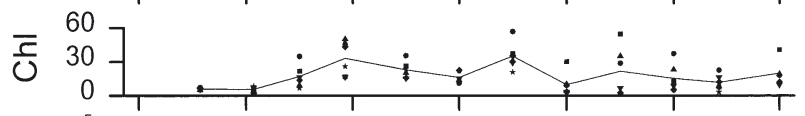

$\begin{array}{ll}E & 10^{5} \\ \pi & 10^{4} \\ \mathbb{Z} & 10^{3} \\ \varangle & 10^{2}\end{array}$ 7-Mar 21-Mar 4-Apr 18-Apr 2-May 16-May 30-May

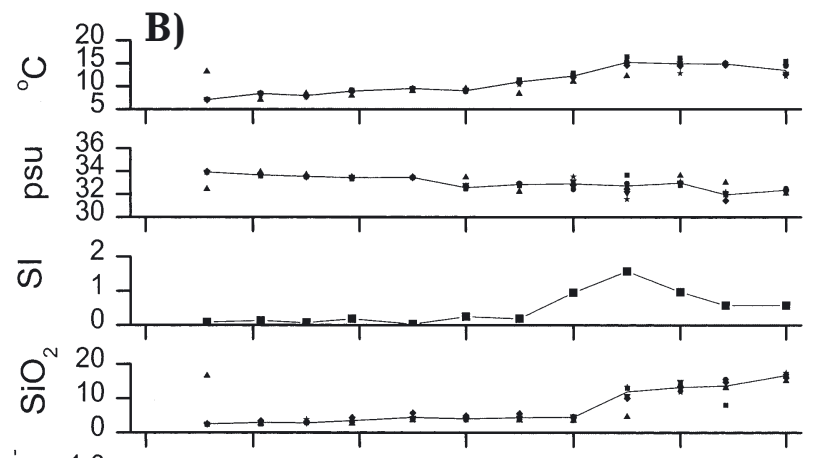

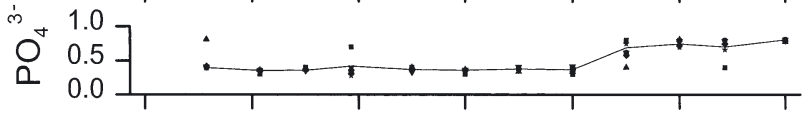

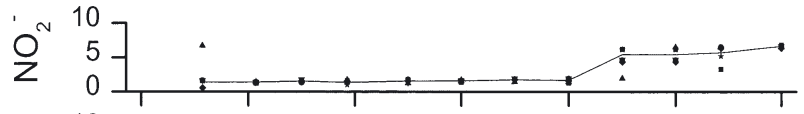

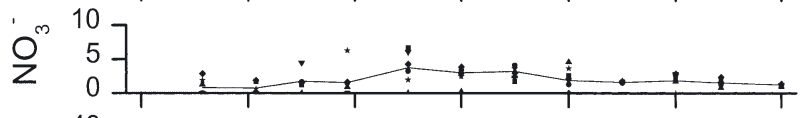

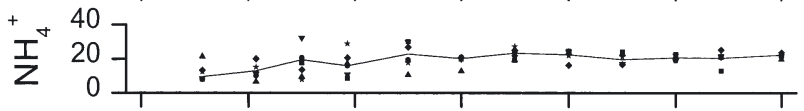

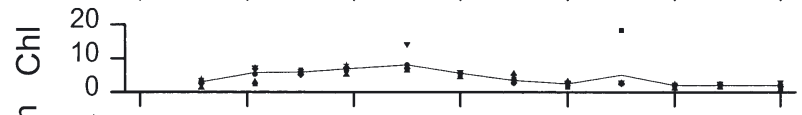

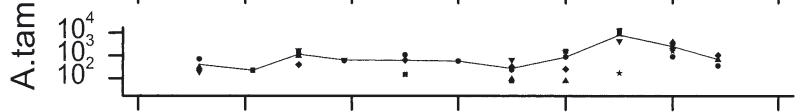

7-Mar 21-Mar 4-Apr 18-Apr 2-May 16-May 30-May

(C) $\begin{aligned} & 20 \\ & 15\end{aligned}$

( $\begin{gathered}20 \\ 15 \\ 10 \\ 5\end{gathered}$

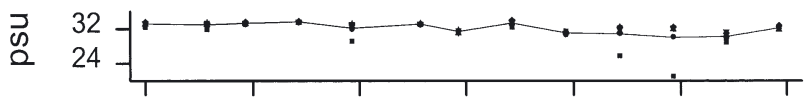

๘ $\begin{array}{r}12 \\ 8 \\ 4\end{array}$

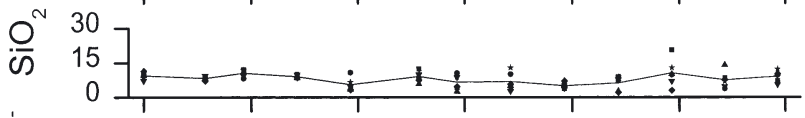

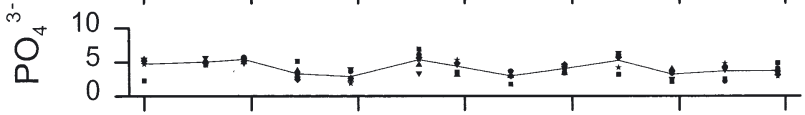

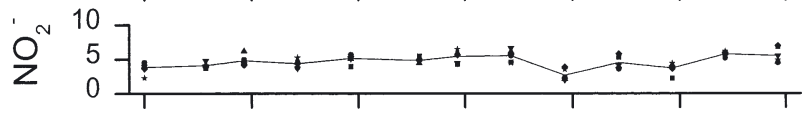

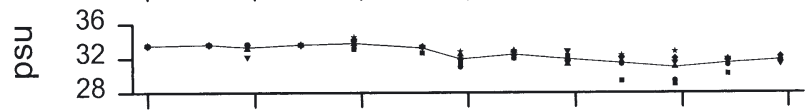

क 2

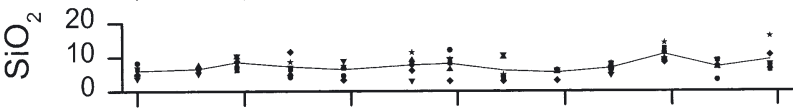

$\left.\mathrm{O}^{+} \begin{array}{r}10 \\ 0\end{array}\right]+\ldots$

$\left.\mathrm{O}^{2} \begin{array}{c}20 \\ Z\end{array}\right]$

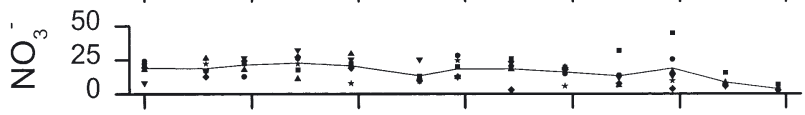

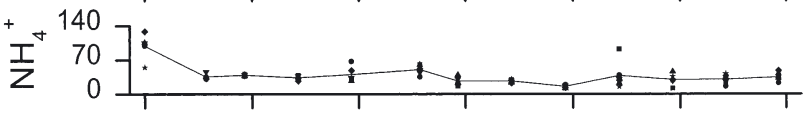

兵 $\left.\begin{array}{c}80 \\ 0 \\ 0\end{array}\right], \ldots$

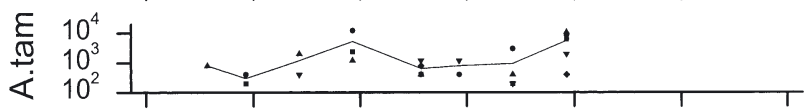

7-Mar 21-Mar 4-Apr 18-Apr 2-May 16-May 30-May

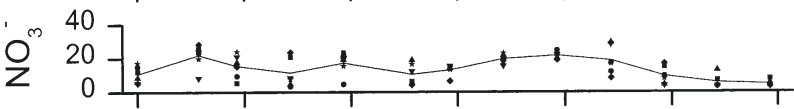

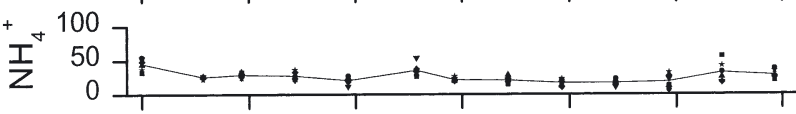

兵 $\left.\begin{array}{r}10 \\ 5\end{array}\right]$

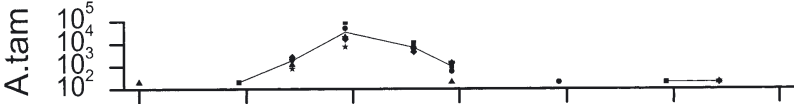
7-Mar 21-Mar 4-Apr 18-Apr 2-May 16-May 30-May 
Fig. 3. Time-series plot for (A) Stn M1 in 1996, (B) Stn C1 in 1996, (C) Stn M2 in 1997, (D) Stn C2 in 1997. Water temperature $\left({ }^{\circ} \mathrm{C}\right)$, salinity (psu), stratification index (SI), inorganic nutrients $(\mu \mathrm{M})$, chl a $\left(\mu \mathrm{g} \mathrm{l}^{-1}\right)$ and Alexandrium tamarense $\left(\right.$ A.tam; cells $\left.\mathrm{l}^{-1}\right)$ are shown. Measurement depths are: filled squares, $0 \mathrm{~m}$; circles, $2 \mathrm{~m}$; upper triangles, $4 \mathrm{~m}$; lower triangles, $6 \mathrm{~m}$; diamonds, $8 \mathrm{~m}$; stars, $12 \mathrm{~m}$. Lines represent average values. Note that the scales for the parameters among figures are different, which was necessary in order to better visualize the temporal patterns

and M2. An early bloom occurred at low temperature $\left(12^{\circ} \mathrm{C}\right.$ and $\left.32 \mathrm{psu}\right)$ at Stn $\mathrm{M} 1$, and was followed by another of similar magnitude at a higher temperature $\left(17^{\circ} \mathrm{C}\right.$ and $\left.31 \mathrm{psu}\right)$. At Stn M2, the first bloom occurred at $13^{\circ} \mathrm{C}$ and $31 \mathrm{psu}$, and was followed by a second larger bloom at $18^{\circ} \mathrm{C}$ and $32 \mathrm{psu}$. Meanwhile, there was only one bloom at Stns C1 and C2. The bloom at Stn $\mathrm{C} 1$ appeared late at high temperature $\left(15^{\circ} \mathrm{C}\right.$ and 33 psu) while a larger bloom at Stn C2 appeared early at low temperature $\left(11^{\circ} \mathrm{C}\right.$ and $\left.33 \mathrm{psu}\right)$. All of the blooms occurred near the surface, except at Stn M2, where the bloom was observed at 2 to $4 \mathrm{~m}$ depth. The onset of the bloom was highly correlated with temperature at all sites (correlation coefficient $r=0.61$ to $0.82, p<0.05$ ) and with water column stratification $(\mathrm{r}=0.82, \mathrm{p}<0.01$ at Stns M1 and C1). Growth rates during the onset of the blooms were greater at Stns C2 and M1 (0.21 to $0.47 \mathrm{~d}^{-1}$ ) than at Stns C1 and M2 (0.18 to $\left.0.22 \mathrm{~d}^{-1}\right)$; the latter stations may have been subjected to greater advection and dispersion by freshwater discharge or tidal currents.

\section{DISCUSSION}

Various physicochemical and biological factors have been proposed for initiating the onset of Alexandrium tamarense blooms, and these factors often interplay to promote the blooms. One major feature in this study was the inconsistency among the sites in time, magnitude, and number of bloom developments. A spring temperature increase initiates the germination of resting cysts, but can also be a contributing factor to bloom termination. A. tamarense in the temperate zone is mainly distributed in low temperature waters of 7 to $15^{\circ} \mathrm{C}$ (Fukuyo 1982, Taylor 1984, Yamamoto et al. 1995, Kim et al. 1996, Mendez et al. 1996). The germination temperature may vary, but was $<8^{\circ} \mathrm{C}$ in this study (Kim et al. 2002), and the upper-end temperature for a bloom to occur was higher at $18^{\circ} \mathrm{C}$. Spring germination rates were $>50 \%$ at water temperatures between 10.0 and $16.5^{\circ} \mathrm{C}$, with an average germination time of $10 \mathrm{~d}$, but sharply dropped or were nil at higher temperatures in Hiroshima Bay, Japan (Itakura \& Yamaguchi 2001). Motile cells were first found at $9^{\circ} \mathrm{C}$ in Golfo Nuevo, Argentina, and the cell density was highest in austral spring and declined sharply toward summer (Gayoso 2001). At high water temperatures of 15 to $20^{\circ} \mathrm{C}$ in late spring, A. tamarense blooms are typically in decline (Anderson et al. 1983). Temperature control of the blooms was observed in this study. At Stn M1, the second and larger bloom appeared at $17^{\circ} \mathrm{C}$ and $32 \mathrm{psu}$, but diminished rapidly, soon after the water column was stratified, which may have been due to persistent high temperatures that could have terminated the bloom.

In comparison with other phytoplankton, dinoflagellates exhibit greater biophysical vulnerability to turbulence and greater bloom dependence on water-mass stratification (e.g. diatoms, Anderson \& Stolzenbach 1985, Smayda 1997, Estrada \& Berdalet 1998). The strong correlations of Alexandrium tamarense abundance with water column stratification index (SI) support the idea that water column stability is crucial for the initiation and demise of the bloom of this species. At Stn M1, A. tamarense density almost followed the

Table 1. Range (min.-max.) and average values (in parentheses) of water temperature $\left(\mathrm{T}_{i}{ }^{\circ} \mathrm{C}\right)$, salinity $\left(\mathrm{S}_{i}\right.$ psu), stratification index $(\mathrm{SI} ;$ largest - smallest water density value at each sampling time), inorganic nutrients $\left(\mathrm{NH}_{4}{ }^{-}, \mathrm{NO}_{3}{ }^{-}, \mathrm{NO}_{2}{ }^{-}, \mathrm{PO}_{4}{ }^{3-}, \mathrm{SiO}_{2}\right.$, all in $\left.\mu \mathrm{M}\right)$, chl a $\left(\mu \mathrm{g} \mathrm{l}{ }^{-1}\right)$, Alexandrium tamarense $\left(\mathrm{A} \mathrm{tam} ; \times 10^{3}\right.$ cells $\mathrm{l}^{-1}$ ), phytoplankton abundance $\left(\right.$ Phyto; $\times 10^{3} \mathrm{cells}^{-1}$ ), and relative abundance of $A$. tamarense to total phytoplankton abundance (A.tam/Phyto; \%). ND: not detectable

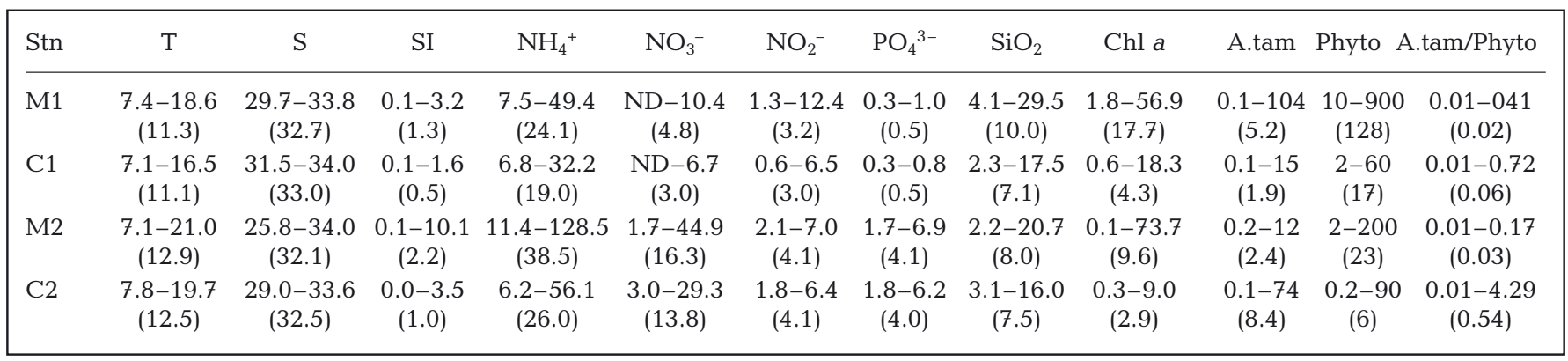


temporal trend of water column stratification (Fig. 3B). The first small increase at Stn M1 occurred at the end of March when the water temperature was close to $10^{\circ} \mathrm{C}$, but it soon declined, probably because the water column was not stabilized. The first bloom appeared around May 1 when the water column became the most stratified. The absence of an early bloom and the bloom decline around May 16 at Stn C1 may also have been attributed to the fluctuation in water column stability, for other environmental conditions (e.g. optimal temperature) appeared to be in favor of growth.

Increased water temperature, rain and subsequent freshwater input, and low wind speeds can all contribute to increased stabilization of the water column. However, prolonged high-wind events can adversely affect blooms by disrupting the water column. Weak winds favored the continued Alexandrium tamarense bloom in the Gulf of St. Lawrence, but winds $>8 \mathrm{~m} \mathrm{~s}^{-1}$ disrupted the bloom (Weise et al. 2002). A week-long wind event $>4 \mathrm{~m} \mathrm{~s}^{-1}$ interrupted the bloom in the Strait of Georgia (Yin et al. 1996). The maximum wind speed in both years was $<4.0 \mathrm{~m} \mathrm{~s}^{-1}$ and lasted only $1 \mathrm{~d}$ or so (Fig. 2); hence, it was not likely to have influenced the bloom initiation of $A$. tamarense.

For water-drifting phytoplankton to build up their biomass in the water column, their growth rate should be greater than the removal rate by water movements of advection and dispersion. While river runoff stabilizes the water column via a buoyancy effect, it may also act to displace cells from the area. Under the influence of large dilution, apparent growth rate would become subdued, or even zero or negative, and thus may determine the size of bloom. The early large bloom at Stn C2 was not followed by any further bloom event, even though the condition appeared to be favorable for growth, except for the large drop in salinity due to the precedent large riverine runoff (Fig. 2). A similar incidence may have occurred at Stn M1 on May 9 when the cell density suddenly dropped from the previous level, concurrently with the decline in salinity, but then the phytoplankton grew back rapidly with the recovery in salinity. Alexandrium tamarense grows well in a wide range of salinities (Anderson et al. 1983, Kim et al. 1996, Weise et al. 2002); therefore, the decline of cell abundance in response to the declining salinity may have been due to a physical dilution process. The effect of dilution on the magnitude of blooms can also be inferred from the difference in growth rates. Converting the difference in growth rate among sites into cell abundance of $A$. tamarense rendered the abundance more comparable among sites. Further, at Stn M2, which was under direct influence of river runoff, unlike the other sites where the blooms appeared at the surface, the bloom was formed in the 2 to $4 \mathrm{~m}$ layer, implying that the surface bloom which may have been present might have been flushed out by a downward flow (Fig. 3D).

Among factors crucial to the development of Alexandrium tamarense is the availability of nutrients, especially N. Toxic Alexandrium spp. blooms occur typically during late spring, when nutrients are depleted by early phytoplankton blooms (Anderson 1997). A. tamarense could take advantage of this shortage of nutrients by migrating to the bottom layer which is relatively rich in nutrients, especially in $\mathrm{N}$-depleted coastal waters (MacIntyre et al. 1997). The average nutrient concentration in this study was high, with no apparent surface depletion (Table 1, Fig. 3). Elevated nutrient levels may have led to a lack of diel vertical migration of $A$. tamarense (H.-O. Lee unpubl. data). The lack of surface depletion of N-nutrients may also have taken away the relative advantage of this flagellated motile phytoplankton over other phytoplankton, and may be responsible in part for the $A$. tamarense abundance being only a small fraction of total phytoplankton abundance (Fig. 3). Together, these results indicate that nutrient availability was not a limiting factor for the bloom development of $A$. tamarense.

Biological factors (e.g. predation) can regulate the bloom of Alexandrium tamarense. It has been shown that zooplankton grazing can suppress the population size of toxic dinoflagellates (White 1981). Grazing by Favella sp., a ciliate and larvae of the polychaete Polydora ligni, significantly reduced the population density of A. tamarense at Cape Cod, Massachusetts (Watras et al. 1985). Acartia hudsonica, a copepod grazer, could daily deplete as much as $70 \%$ of the Alexandrium sp. biomass in the Gulf of Maine (Campbell et al. 2000). In the present study, Acartia omorii was a dominant zooplankton, in abundance terms, in Chinhae Bay (Kang et al. 1996), but its grazing on A. tamarense was insignificant to influence the population (H.-O. Lee unpubl. data). Possible explanations for this result would be that $A$. omorii may reject some dinoflagellates by a chemically mediated process (Uye \& Takamatsu 1990) or that it preferentially grazes on diatoms (Uchima 1988) or fecal pellets (Ayukai 1986).

There is a growing body of evidence that other biological factors are responsible for the rapid decline of harmful algal blooms. Algicidal bacteria and viruses have been demonstrated to be agents responsible for terminating harmful algal blooms in aquatic environments (Nagasaki et al. 1994, Jacobsen et al. 1996, Manage et al. 2000). Bacteria that promote Alexandrium tamarense and Alexandrium catenella to form cysts have been suggested in controlling their bloom dynamics in Hiroshima Bay, Japan (Adachi et al. 1999), and the possible influence of such factors on the demise of $A$. tamarense in Chinhae Bay needs to be investigated in future studies. 
Meanwhile, life-cycle transitions have been demonstrated to be linked to Alexandrium tamarense bloom decline (Anderson et al. 1983, Anderson 1998). A. tamarense, as for other potentially toxic species, forms cysts as a result of sexual reproduction under unfavorable conditions (e.g. nutrient limitation, temperature increase, and destratification). Anderson et al. (1983) showed that the sexuality of $A$. tamarense was induced well before the population peak, and planozygotes, the intermediate life stage form, comprised 20 to $40 \%$ of the motile population during the late stage of a bloom, when conditions were still favorable for growth. In the present study, both planozygotes and vegetative cells were observed at all sites during the blooms of $A$. tamarense (H.-O. Lee pers. obs.). It was evident, however, that environmental conditions when A. tamarense abundance started to decline were often not hostile for growth: optimal water temperature $\left(<18^{\circ} \mathrm{C}\right)$, salinity (31 to $33 \mathrm{ppt}$ ), a stratified water column, and high ambient nutrient concentrations (Table 1). Sexual reproduction may be initiated independently of environmental cues (Anderson et al. 1983).

In summary, the onset and demise of Alexandrium tamarense blooms in Chinhae Bay were formed by several factors. A stable water column was necessary for bloom initiation at both low and high temperatures. A bloom demise could be related to prolonged high temperatures or less stable water column or physical dilution processes. Physical dilution appeared to determine the magnitude of the bloom. Life-cycle transition may also have been important for bloom termination, especially under favorable environmental conditions.

Acknowledgements. We are grateful to Professor Ishimaru for his interest in this study. Kyung-Hoon Hyun helped compute the water density data. We also thank Lisa Drake, David Caron, and 3 anonymous reviewers for their constructive comments which greatly improved the quality of this manuscript. This research was supported by the National Research Laboratory Program (2000-N-NL-01-C-290) of the Korean Ministry of Science and Technology.

\section{LITERATURE CITED}

Adachi M, Kanno T, Matsubara T, Nishijima T, Itakura S, Yamaguchi M (1999) Promotion of cyst formation in the toxic dinoflagellate Alexandrium (Dinophyceae) by natural bacterial assemblages from Hiroshima Bay, Japan. Mar Ecol Prog Ser 191:175-185

Anderson DM (1997) Bloom dynamics of toxic Alexandrium species in the northeastern US. Limnol Oceanogr 42: 1009-1022

Anderson DM (1998) Physiology and bloom dynamics of toxic Alexandrium species, with emphasis on life cycle transitions. In: Anderson DM, Cembella AD, Hallegraeff GM (eds) Physiological ecology of harmful algal blooms. NATO-Advanced Study Institute Series, Vol 41. SpringerVerlag, Heidelberg, p 29-48
Anderson DM, Stolzenbach KD (1985) Selective retention of two dinoflagellates in a well-mixed estuarine embayment: the importance of diel vertical migration and surface avoidance. Mar Ecol Prog Ser 25:39-50

Anderson DM, Chisholm SW, Watras CJ (1983) Importance of life cycle events in the population dynamics of Gonyaulax tamarensis. Mar Biol 76:179-189

Ayukai T (1986) Rate of filtering of fecal pellets by Acartia omorii (Copepoda; Calanoida). J Oceonogr Soc Jpn 42: 487-489

Campbell RG, Teegarden GJ, Cembella AD, Durbin EG (2000) Zooplankton grazing impacts on Alexandrium sp. in the Gulf of Maine. Ninth Int Conf Harmful Algal Blooms, Tasmania

Cembella AD, Therriault JC (1989) Population dynamics and toxin composition of Protogonyaulax tamarense from the St. Lawrence estuary. In: Okaichi $\mathrm{T}$, Anderson DM, Nemoto T (eds) Red tides: biology, environmental science and toxicology. Elsevier, New York, p 81-84

Cho $\mathrm{CH}$ (1979) Mass mortalities of oyster due to red tide in Chinhae Bay in 1978. Bull Korean Fish Soc 12:27-33

Cleveland WS (1993) Visualizing data. Hobart Press, Summit, NJ

Estrada M, Berdalet E (1998) Effects of turbulence on phytoplankton. In: Anderson DM, Cembella AD, Hallegraeff GM (eds) Physiological ecology of harmful algal blooms. NATO-Advanced Study Institute Series, Vol 41. SpringerVerlag, Heidelberg, p 601-618

Franks PJS, Anderson DM (1992) Toxic phytoplankton blooms in the southwestern Gulf of Maine: testing hypotheses of physical control using historical data. Mar Biol 112:165-174

Fukuyo Y (1982) Taxonomical and ecological studies on Protogonyaulax occurring in Japanese coastal waters. PhD thesis, University of Tokyo (in Japanese)

Gayoso AM (2001) Observations on Alexandrium tamarense (Lebour) Balech and other dinoflagellate populations in Golfo Nuevo, Patagonia (Argentina). J Plankton Res 23: 463-468

Han MS, Jeon JK, Kim YO (1992) Occurrence of dinoflagellate Alexandrium tamarense, a causative organism of paralytic shellfish poisoning in Chinhae Bay, Korea. J Plankton Res 14:1581-1592

Itakura S, Yamaguchi M (2001) Germination characteristics of naturally occurring cysts of Alexandrium tamarense (Dinophyceae) in Hiroshima Bay, Inland Sea of Japan. Phycologia 40:263-267

Jacobsen A, Bratbak G, Heldal M (1996) Isolation and characterization of a virus infecting Phaeocystis pouchetii (Prymnesiophyceae). J Phycol 32:923-927

Jeon JK, Yi SK, Huh HT (1988) Paralytic shellfish poisoning of bivalves in the Korean waters. J Oceanol Soc Korea 23: 123-129

Kang YS, Park JS, Lee SS, Kim HG, Lee PY (1996) Zooplankton community and distributions of copepods in relation to eutrophic evaluation in Chinhae Bay. J Korean Fish Soc 29:415-430

Kim CH, Lee JS (1996) Occurrence of toxic dinoflagellates and PSP toxin profiles in Alexandrium spp. from Jinhae Bay, Korea. In: Yasumoto T, Oshima Y, Fukuyo Y (eds) Harmful and toxic algal blooms. IOC/UNESCO, Paris, p 61-64

Kim CH, Sako Y, Ishida Y (1993) Comparison of toxin composition between populations of Alexandirum spp. from geographically distant areas. Nippon Suisan Gakkaishi 59: 641-646

Kim CK (1994) Three-dimensional numerical model experi- 
ments of tidal and wind-driven currents in Chinhae Bay. J Oceanol Soc Korea 29:95-106

Kim CK, Chang SD, Lee JS (1994) Two-dimensional hydraulic and numerical modelingof tidal currents in Chinhae Bay. J Oceanol Soc Korea 29:83-94

Kim HG, Lee SG, Lim WA, Lee JS, Kim JH (1996) Environmental physiology of Alexandrium tamarense isolated from Chinhae Bay, the South Sea of Korea. In: Yasumoto T, Oshima Y, Fukuyo Y (eds) Harmful and toxic algal blooms. IOC/UNESCO, Paris, p 57-60

Kim YO, Park MH, Han MS (2002) Role of cyst germination in the bloom initiation of Alexandrium tamarense (Dinophyceae) in Masan Bay, Korea. Aquat Microb Ecol 29: 279-286

Lee HO, Cheun BS, Watanabe E, Han MS (2000) Comparison of HPLC analysis and a channel biosensor in the detection of PSP toxin in a natural Alexandrium tamarense population. Algae 15:61-64

Lee JB, Kim DY, Lee JA (1998) Community dynamics and distribution of dinoflagellates and their cysts in MasanChinhae Bay, Korea. J Fish Sci Technol 1:283-292

Lee KW, Hong GH, Yang DB, Lee SH (1981) Seawater quality and red tides in Jinhae Bay: I. Relationships between water quality parameters and red tides. J Oceanol Soc Korea 16:43-48

Lee SG (1990) Identification of three dinoflagellate species belonging to the genus Alexandirum occurring in Chinhae Bay. Bull Fish Res Dev Agency 44:1-8

MacIntyre JG, Cullen JJ, Cembella AD (1997) Vertical migration, nutrition and toxicity in the dinoflagellate Alexandrium tamarense. Mar Ecol Prog Ser 148:201-216

Manage PM, Kawabata Z, Nakano S (2000) Algicidal effect of the bacterium Alcaligenes denitrificans on Microcystis spp. Aquat Microb Ecol 22:111-117

Mendez S, Severov D, Ferrari G, Mesones C (1996) Early spring Alexandrium tamarense toxic blooms in Uruguayan Waters. In: Yasumoto T, Oshima Y, Fukuyo Y (eds) Harmful and toxic algal blooms. IOC/UNESCO, Paris, p 113-116

Nagasaki K, Ando M, Imai I, Itakura S, Isida Y (1994) Viruslike particles in Heterosigma akashiwo (Raphidophyceae): a possible red tide disintegration mechanism. Mar Biol 119:307-312

Parsons TR, Maita Y, Lalli CM (1992) A manual of chemical and biological methods for seawater analysis. Pergamon Press, Oxford

Smayda TJ (1997) Harmful algal blooms: their ecophysiology and general relevance to phytoplankton blooms in the sea. Limnol Oceanogr 42:1137-1153

Su HM, Chiang YM, Liao CH (1993) Role of temperature, salinity and ammonia on the occurrence of the Taiwanese strain of Alexandrium tamarense. In: Smayda TJ, Shimi Y

Editorial responsibility: David Caron,

Los Angeles, California, USA (eds) Toxic phytoplankton blooms in the sea. Elsevier, Amsterdam, p 837-842

Taylor FJR (1984) Toxic dinoflagellates: taxonomic and biogeography aspects with emphasis on Protogonyaulax. In: Ragelis EP (ed) Seafood toxins. ACS Symposium Series 262. American Chemical Society, Washington, p 77-97

Therriault JC, Painchaud J, Levasseur M (1985) Controlling the occurrence of Protogonyaulas tamarense and shellfish toxicity in the St. Lawrence Estuary: freshwater runoff and the stability of the water column. In: Anderson DM, White AW, Baden DG (eds) Toxic dinoflagellates. Elsevier, New York, p 141-146

Uchima M (1988) Gut content analysis of neritic copepods Acartia omorii and Oithona davisae by a new method. Mar Ecol Prog Ser 48:93-97

Uye S, Takamatsu K (1990) Feeding interactions between planktonic copepods and red-tide flagellates from Japanese coastal waters. Mar Ecol Prog Ser 59:97-107

Watras CJ, Chisholm SW, Anderson DM (1982) Regulation of growth in an estuarine clone of Gonyaulax tamarense Lebour: salinity-dependent temperature responses. J Exp Mar Biol Ecol 62:25-37

Watras CJ, Garcon VC, Olson RJ, Chisholm SW, Anderson DM (1985) The effect of zooplankton grazing on estuarine blooms of the toxic dinoflagellate Gonyaulax tamarensis. J Plankton Res 7:891-908

Weise AM, Levasseur M, Saucier FJ, Senneville S and 5 others (2002) The link between precipitation, river runoff, and blooms of the toxic dinoflagellate Alexandrium tamarense in the St. Lawrence. Can J Fish Aquat Sci 59: $464-473$

White AW (1981) Marine zooplankton can accumulate and retain dinoflagellate toxin and cause fish kills. Limnol Oceanogr 26:103-109

White AW (1987) Relationships of environmental factors to toxic dinoflagellate blooms in the Bay of Fundy. Rapp P-V Reun Cons Int Explor Mer 187:38-46

Wyatt T, Jenkinson IR (1997) Notes on Alexandrium population dynamics. J Plankton Res 19:551-575

Yamamoto T, Yoshizu Y, Tarurani T (1995) Effects of temperature, salinity and irradiance on the growth of toxic dinoflagellate Alexandrium tamarense isolated from Mikawa Bay, Japan. Jpn J Phycol 43:91-98

Yang DB (1989) Nutrients and chlorophyll a variations during the red tides in Jinhae Bay, Korea. In: Okaichi $\mathrm{T}$, Anderson DM, Nemoto T (eds) Red tides: biology, environmental science, and toxicology. Elsevier, Amsterdam, p 237-240

Yin K, Harrison PJ, Goldblatt RH, Beamish RJ (1996) Spring bloom in the Central Strait of Georgia: interactions of river discharge, winds and grazing. Mar Ecol Prog Ser 138: $255-263$

Submitted: March 15, 2002; Accepted: June 10, 2003

Proofs received from author(s): October 28, 2003 